\title{
Commons committee criticizes information technology spending
}

London

THE British government's failure to tackle effectively the balance-of-trade deficit in information technology (IT) was criticized last week in a scathing report by the House of Commons Trade and Industry Committee. It accuses the government of complacency about the negative trade balance, which stood at $£ 2,226$ million in 1987. The government does not attach high priority to IT as a frontier technology needing sponsorship, it says, and this attitude does not promote use of IT in the economy. More funding for IT research is recommended as well as measures to tackle the country's "deplorable" and "worsening" skills shortage in this field.

Applications for places on university and polytechnic computer science courses fell by 38 per cent last year and the Committee of Vice-Chancellors and Principals (CVCP) expects a shortfall of a quarter in the number of students for computer science courses in 1989-90; the number planned for was about 7,000. The shortage of skilled people at present is estimated to be about one-tenth of the total number of IT professionals in users' and suppliers' companies. The committee received evidence of 30,000 unfilled vacancies for people with IT skills. This situation is "deplorable", and will take time to redress as "serious inadequacies" in the schools and in higher education are unlikely to be resolved swiftly. The country faces a crisis in both quantity and quality of people with

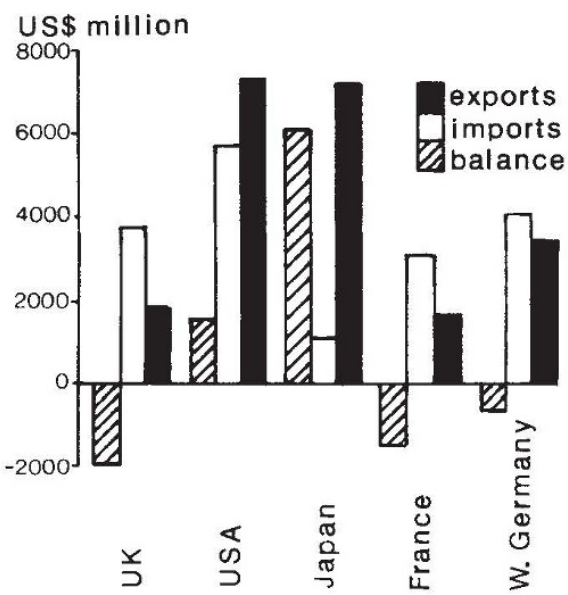

Trade balance in electronic data processing equipment in 1986. (Source: DTI.)

IT skills, says the committee.

One way to tackle this would be to increase the number of undergraduate and postgraduate courses in IT, and the committee recommends that a working party be set up urgently with the Department of Education and Science, the higher education funding councils and the business sector in order to do this.
But the best solution to the skills shortage is increased in-service training, says the committee. It calls on the government to prove with statistics that companics are now spending more money on training, as it says they are. And it recommends that expenditure on training should be disclosed in company accounts.

The country's comparatively poor IT performance is also linked to expenditure on research and development. The committee was told by the CVCP that the highest proportion of unfunded alpharated proposals supported by the Science and Engineering Research Council (SERC) is in computer science. Worthwhile research is going unsupported and Britain is not maintaining the proportion of its gross domestic product spent on research and development, says the committee. It finds no clear rationale for how IT research priorities are chosen and how the amount of money spent on each is determined. And it recommends that the Department of Trade and Industry (DTI) should consider increasing by $£ 10$ or $£ 20$ million its annual expenditure on alpharated computer science research projects and the accepted projects of the national programme.

In conjunction with Britain's contribution to the European Commission's Esprit 2 programme, the national programme is now the main thrust of the country's IT research, replacing the Alvey programme, and is funded by the DTI and SERC. Alvey was designed to ensure that the country's IT industry could compete with Japan and the United States in the world market. But the committee doubts whether this has been achieved.

To encourage industry to spend more, the committee suggests that the government should identify the level of research to be carried out in the IT industry so that companies could aspire to this standard. But it suggests that tax incentives be considered for research and development carried out in small and new companies.

And it recommends that value-added tax should be waived on donations of equipment and software given by companies to universities. The tax rules should also be altered so as not to discriminate against donations which are for advertising and philanthropic purposes.

The implementation of the single European market in 1992 could herald more problems for Britain's IT industry. There is a real danger, says the committee, that the opening up of the European market will create opportunities for Japanese and US companies that will not be balanced by equal access for European companies to those markets.

\section{Coordinated US science budget}

\section{Washington}

MORE attention needs to be paid to developing a "cross-agency perspective" to unify and direct US government spending on research, according to a report* released this week by a joint committee from the US National Academy of Sciences, the National Academy of Engineering and the Institute of Medicine.

The committee concluded that, although the budget process for supporting research within an individual agency is working adequately, more effort is needed to ensure that the total US expenditure in science and technology matches the country's needs and priorities.

The committee was asked by Congress in the summer, after the annual budget process had been completed, to examine how well the current budget process works. Congress was concerned that coordination of the $\$ 60,000$ million dedicated to science and technology in the federal budget - spread over more than 30 agencies and institutions - was becoming too cumbersome and disjointed.

The joint committee recommends that the president, with the advice of his science adviser, should provide federal agencies with an outline of a national science agenda early in the budget cycle. Agency heads could then ask for money for inter-agency programmes without having to justify them exclusively within their own terms of reference. Supplied with a clearer picture of the funds needed by each agency to accomplish national goals, Congress would then be better equipped to judge the president's budget request.

The committee suggests that the science budget be broken down into four categories: research necessary to accomplish individual agency missions; inter-agency programmes which support the science base, such as education and basic research; projects important to national objectives, such as enhancing economic competitiveness; and major long-range plans, such as the space station or sequencing the human genome. Because the last three categories cut across agency boundaries, they would be evaluated by Congress against the president's overall plan.

The committee also asks that PresidentElect George Bush should appoint a group of experts to determine how much of the defence budget can appropriately be included in estimates of US research efforts. At present, spending on defence research accounts for two thirds of the total federal spending for science

Carol Ezzell

*Federal Science and Technology Budget Priorities New Perspectives and Procedures, 1988, is available from the National Academy Press, Washington, DC. 